\title{
Using photography to elicit grazier values and management practices relating to tree survival and recruitment
}

\author{
Kate Sherren ${ }^{\mathrm{a}, *}$, Joern Fischer ${ }^{\mathrm{a}}$, Richard Price ${ }^{\mathrm{a}, \mathrm{b}}$ \\ a Fenner School of Environment and Society, Australian National University, Canberra, ACT 0200, Australia \\ ${ }^{\mathrm{b}}$ Kiri-ganai Research Pty. Ltd., GPO Box 103, Canberra, ACT 2601, Australia
}

\section{A R T I C L E I N F O}

\section{Article history:}

Received 4 December 2009

Received in revised form 8 February 2010

Accepted 10 February 2010

\section{Keywords:}

Photo-elicitation

Scattered trees

Fertiliser

Rotational grazing

Landscape values

Holistic resource management

\begin{abstract}
A B S T R A C T
Integrating conservation and agricultural production is a major challenge globally. The upper Lachlan catchment of Australia is dominated by livestock grazing, and is threatened because most native woodland vegetation has been cleared. A third of all remaining tree cover occurs as scattered trees in grazing pastures. These scattered trees are dying from old age and are not regenerating due to grazing pressure. Previous work has revealed management strategies that are more likely to maintain tree cover, such as low-input rotational grazing. We asked graziers to photograph significant features on their properties, and used the images as prompts in later interviews. This elicited graziers' landscape values and other drivers of their management practices related to tree cover. The targets that our 25 case landholders chose to photograph, and the ways they discussed them in later interviews, reflected the focus of past education and incentive programs, suggesting that well-designed policies, educational messages and incentives do seem to reach landholders and result in improved practices. For example, many landholders reported management activities related to the protection of large woodland patches or the maintenance of coarse woody debris. The maintenance of scattered tree cover has not been a focus of policy initiatives in the past. Despite this, the narratives elicited by photos of isolated and scattered trees showed graziers valued them and were aware of and concerned about their decline, yet lacked knowledge about how to protect and regenerate them. Graziers urgently need unambiguous advice and practical assistance to help them adapt their practices to maintain scattered trees in the long term.
\end{abstract}

(c) 2010 Elsevier Ltd. All rights reserved.

\section{Introduction}

In a context of global agricultural intensification, the management decisions of individual farmers have an increasing impact on environmental conditions world-wide (Foley et al., 2005; Hoekstra et al., 2005; Tscharntke et al., 2005). While governments and corporations make the macro-level decisions that influence what gets managed and where, individual farmers make countless microlevel decisions about how it is done. Those looking to improve agricultural practices typically leverage policy settings and market drivers to change management, but landholder decision-making processes are often more complicated (Lal et al., 2001; McGuckian and Rickards, 2009). In a 1939 speech titled "The farmer as a conservationist", Aldo Leopold observed that "the landscape of any farm

\footnotetext{
* Corresponding author at: Fenner School of Environment and Society, Australian National University, Building 43 Biology Place, Canberra, ACT 0200, Australia. Tel.: +6126125 7156; fax: +61261252737.

E-mail addresses: Kate.Sherren@ANU.edu.au (K. Sherren), Joern.Fischer@ANU.edu.au (J. Fischer), Richard.Price@Kiri-ganai.com.au (R. Price).
}

is the owner's portrait of himself" (Meine, 1987). Using landholder photography as a research methodology harnesses such conceptions of self to expose the complex drivers of agricultural practice.

The Southeastern Australian wheat-sheep belt (Fig. 1) is part of an internationally recognised threatened ecoregion (Hoekstra et al., 2005), and comprises critically endangered ecological communities (DEWHA, 2009). Only approximately 15\% of pre-settlement tree cover remains (Dorrough and Moxham, 2005; Fischer et al., 2009a; Freudenberger et al., 2004). Following land clearing for agriculture (Benson and Redpath, 1997; Lunt et al., 2006; Ozolins et al., 2001 ), large patches of trees ( $>5$ ha) are largely restricted to unproductive ridges that are least suitable for agriculture (Fischer et al., 2009a). By contrast, the actively grazed low-lying areas that comprise the majority of land are dominated by isolated or scattered trees exhibiting an aging demographic profile (Fischer et al., 2009a). These isolated and scattered trees are experiencing a passive yet inexorable form of clearing under active grazing: accelerated tree mortality and failed seedling recruitment (Dorrough and Moxham, 2005; Gibbons et al., 2008). A regional-scale collapse in tree cover is looming, threatening the sustainability of the region (Fischer et al., 2009b). 


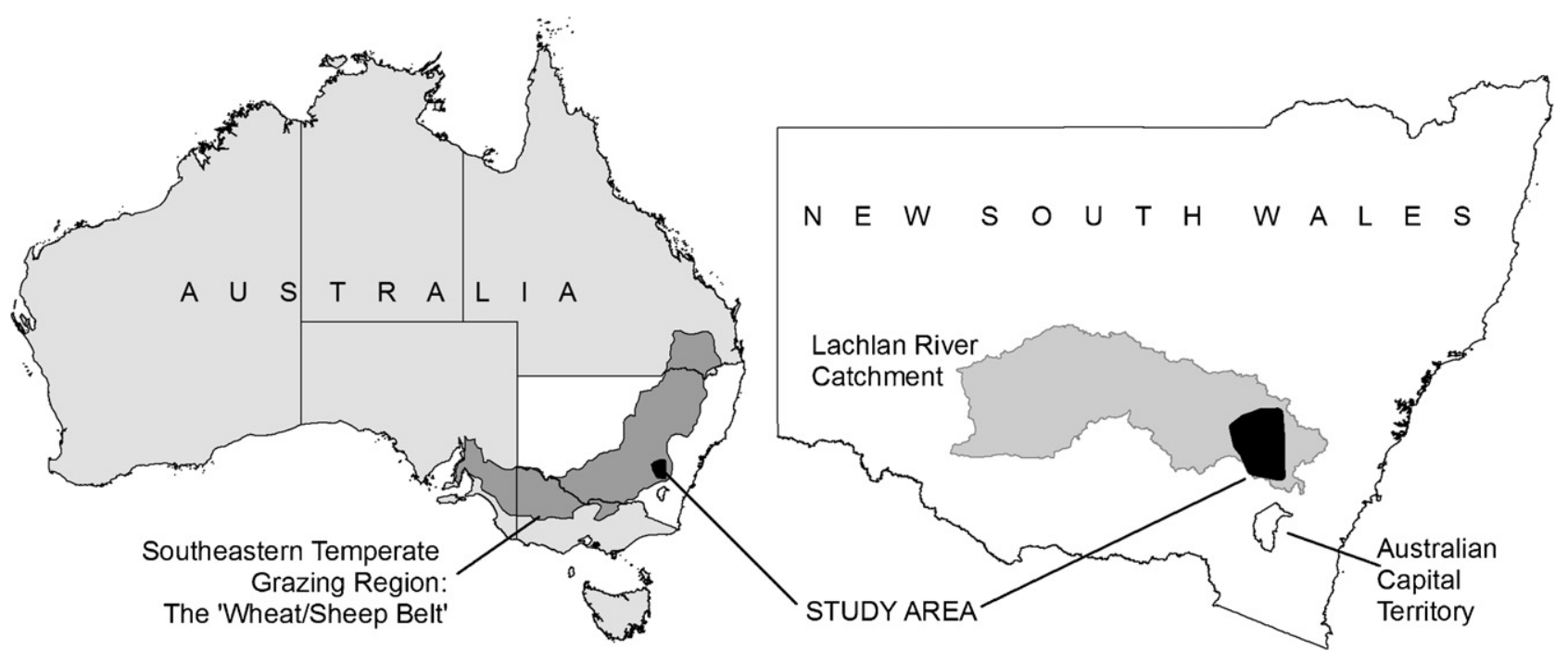

Fig. 1. Map of the study area.

Isolated and scattered trees account for approximately one third of remnant tree cover in the region (Fischer et al., 2009a), and provide valuable ecosystem services. For example, scattered trees improve pasture productivity, provide shade for livestock, enhance water infiltration, and constitute habitat for many species of bats and birds (Bird et al., 1992; Dorrough et al., 2004; Eldridge and Freudenberger, 2005; Lumsden and Bennett, 2005; Manning et al., 2006; Vesk and MacNally, 2006; Walpole, 1999). More generally, scattered trees contribute heterogeneity to an otherwise homogenous landscape matrix, thereby increasing the resilience of the ecosystem to external disturbances, including climate change (Manning et al., 2006, 2009). Despite these values, to date, agencies have addressed tree decline in the region by funding the protection of large patches (Spooner et al., 2002; Spooner and Briggs, 2008 ) or the planting of linear strips, typically along fences or creeks (Bennett et al., 2000; Munro et al., 2009). Large patches and linear plantings have been favoured by a sequence of government programs including the National Landcare Program (Curtis and De Lacy, 1998) and the Natural Heritage Trust (Bardsley et al., 2002), as well as by the non-governmental conservation sector, in particular Greening Australia. The perpetuation of scattered trees has recently been identified as an important complementary priority (Fischer et al., 2009a; Manning and Lindenmayer, 2009). Reversing the region's decline in scattered tree cover calls for the widespread adoption of management practices that are conducive to tree regeneration within grazed areas, rather than simply setting aside land for conservation purposes (Fischer et al., 2008).

This study is part of a larger integrative project that is seeking practical ways to integrate conservation and production in grazing (Sherren et al., in press). We began in 2007 with an ecological study to correlate grazing management histories with the probability of tree recruitment in sites of different tree density and age (Fischer et al., 2009b). That work identified a small set of recommended management practices to perpetuate scattered trees. Active management is needed where natural regeneration is unlikely, such as where there are few parent trees or where soil nutrient levels are greatly elevated. Active management options include planting scattered trees, and protecting them from grazing until established (Fischer et al., 2009b; see also Ozolins et al., 2001). Passive management options to enhance the health of seedlings and parent trees include: (1) decreasing the use of fertiliser; and, (2) using rotational grazing regimes with prolonged rest periods. In addition to enhancing tree recruitment it is considered important that existing mature trees remain as healthy as possible for as long as possible (Gibbons et al., 2008).

Private landholders control the majority (94\%) of land in the region (Tonts et al., 2003), and thus the future of regional tree cover depends on their management decisions. Landholder adoption of any new practice depends, in part, on their values and beliefs (Frost, 2000; Vanclay, 2004). An increasing diversity of benefits from woody vegetation - including production, biodiversity, and aesthetics - is recognised by Australian landholders (Dettman et al., 2000; Hodgkins et al., 1999; Kirkpatrick et al., 2007; Seabrook et al., 2008). However, in a recent survey in the region landholders were less likely to recognise the benefits of scattered trees than those provided by denser and larger patches of trees, and they were less likely to make management decisions in order to protect or regenerate sparse trees (Jacki Schirmer, pers. comm.). Here, we explore how landholders value their working landscapes, and how those values may affect their farm management decisions.

Specifically, this article reports on a photo-elicitation exercise undertaken in collaboration with graziers who had also participated in the ecological study (Fischer et al., 2009b). In photo-elicitation, volunteers take photographs of features meeting pre-defined criteria, and photographs are subsequently used for guiding discussions in qualitative interviews. In this instance, graziers were asked to capture 'significant' farm features. This paper seeks to inform the design of policies to encourage management practices conducive to the long-term maintenance of scattered trees by synthesizing: (1) the landscape priorities suggested by what graziers chose to photograph; and, (2) the key themes that certain popular targets stimulated in subsequent discussions with those graziers.

\section{Background}

Environmentally significant behaviour begins with broad value orientations, for instance toward oneself (egoistic), others (altruistic), or the environment (biospheric) (de Groot and Steg, 2008; Stern, 2000). A person's value orientation influences their "beliefs about human-environment relations, their consequences [for valued objects], and the individual's responsibility for taking corrective action" (Stern, 2000). In this work, no particular position in the above causal chain of values, beliefs, and norms is targeted; what we refer to in this paper as 'landscape values' is a general term embracing all such drivers of behaviour (Gobster et al., 2007). 
There are several ways to learn about a landholder's landscape values. One way is to ask landholders outright in large-scale questionnaires (Byron et al., 2006; Dettman et al., 2000; Hodgkins et al., 1999; Moore and Renton, 2002). This is the dominant method in environmental psychology (Bonaiuto et al., 2002; Davis et al., 2009; Fielding et al., 2008; Frost, 2000). It can be difficult to phrase survey questions appropriately to avoid problems like face validity (Anastasi, 1988) - where the test's intentions are transparent, and the 'right' answer so evident that respondents are able to easily manipulate how 'good' they look. Values elicited from large-scale questionnaires are thus frequently inconsistent with behaviour (Cary, 1993; Jurin and Fortner, 2002; Lawrence et al., 2004).

Even if suitable questions can be designed, it can be difficult for respondents to answer them honestly simply because the internal frames of reference (or 'mental maps') that influence their perceptions and behaviours are held very deeply (Dalton and Dunnett, 1992). Personal construct theory holds that people understand the world through building, refining and applying theories about what they encounter. Each person's set of interpretations and expectations is unique, changeable with experience and often internally-flawed (Fransella and Bannister, 1977). Personal theoretical constructs are not accessed easily through verbal means, but can be revealed through individuals' choices in constrained tasks, such as sorting statements or prioritising areas on a map (e.g. Brodt et al., 2006; Raymond et al., 2009). Semi-creative visual research methods such as rich picturing, gaming, and photography are similarly active and constrained and initially bypass the sometimes unreliable verbal realm (Fischer and Young, 2007; Prosser and Schwartz, 1998; Wyborn and Cleland, in press).

One 'visual' way of exploring landscape values is to ask people to rate or rank the same set of images - real or simulated - on the basis of criteria like aesthetic preference or perceived health (Cañas et al., 2009; Dettman et al., 2000; Williams and Cary, 2002). This method can be used to produce lists of landscape elements or metrics that are likely to contribute to a view's rating on the criteria in question. For instance, landscapes judged as 'scenic' often feature wilderness or naturalness, vegetation cover, water bodies, topographical variety and contrast, and appear well maintained (Arriaza and Canas-Ortega, 2004; Hagerhall et al., 2004; Nassauer, 1995; Ode et al., 2009; Purcell and Lamb, 1998; Rogge et al., 2007; Wu et al., 2006). Such lists can be used to predict the acceptability of alternate landscapes without requiring lengthy stakeholder consultation (Dramstad et al., 2006; Ford et al., 2009; Germino et al., 2001; Hunziker and Kienast, 1999; Palmer, 2004).

Photo-elicitation is a participative research method that captures the singular way that individuals relate to the landscapes in which their own personal stories are embedded (Arler, 2000; Bonaiuto et al., 2002; Gunderson and Watson, 2007; Seabrook et al., 2008; Vouligny et al., 2009). There are two typical parts to photo-elicitation exercises. First, respondents take photographs, and second, those images are used to instigate discussion in qualitative interviews (Collier, 1957). What people do when asked to perform a constrained activity like film-based photography can potentially expose their personal priorities - the 'what' - and following up with interviews allows the basis of those perceptions the 'why' - to be explored.

Photographs are bounded views of reality and thus provide a manageable entry point for discussing complex issues (Harper, 2002), especially when the interviewees capture the images themselves. It is a common methodology in tourism, development and health research, and has been found to be particularly useful when the research is targeting the un-empowered (e.g. children, women, minorities, those with low-literacy), or simply where a shared language or vocabulary is lacking between the respondents and the researchers (Collier, 2001; e.g. Dennis et al., 2009; Garrod, 2007;
Markwell, 1997; Pingjun, 2008; Wang et al., 1996). 'Sense of place' research appropriately also uses respondent photography (Beckley et al., 2007; Moore, 2002; Stedman et al., 2004). While photoelicitation is rare in rural studies, its application has generated some compelling explorations of the challenges and satisfactions of farming life (Beilin, 2005; Moore, 2002).

Photo-elicitation analysis is a less mature practice than questionnaire-based methods, where appropriate statistical methods are widely agreed and applied. Typically, the photographs themselves are simply a means to generate the interview, and are not themselves analysed, although photograph locations have been used in limited spatial analyses (Dennis et al., 2009; Sherren et al., in press). Sometimes the images are prioritised or classified by the photographer(s), although this can make for lengthy interviews (Beilin, 2005). Narratives inspired by photographs are either analysed semi-quantitatively, by coding the key themes evoked using emergent or researcher-defined categories (this work; Beckley et al., 2007), or through less deconstructive and more ethnographic narrative analysis (Beckley et al., 2007; Beilin, 2005; Moore, 2002; Stedman et al., 2004). There are tradeoffs between these two extremes. Quantitative approaches sacrifice the richness of the original interviews in order that the results are easier to defend as representative of the studied population. By contrast, narrative analysis is engaging but often too complex and case-specific for use by policy-makers (Williams and Patterson, 2007). In reality, there exists a spectrum of options between the two (see, for instance, Soliva and Hunziker, 2009); this work leans towards the first, in deference to our goal of informing practice.

\section{Methods}

Our study area encompasses one million hectares in the upper Lachlan River catchment of New South Wales (NSW), Australia (Fig. 1). Farming of sheep, beef cattle and grain are the main industries, but grazing is considerably more dominant on the basis of area ( $72.5 \%$ of our study area, compared with $12.5 \%$ cropping). Thirtyone graziers from the area took part in the biophysical research discussed earlier (Fischer et al., 2009b). They were chosen to represent a range of stocking levels (average stocking rates ranging from 2 to 12 dry sheep equivalent per hectare) and rotation regimes (keeping stock in any given paddock from about 10 to 365 days per year). A small number of farmers also grow crops on parts of their properties, but irrigated cropping (e.g. involving centre-pivot irrigation systems) is virtually absent in our study area.

\section{Data collection}

The same landholders who participated in the ecological study were contacted by phone and asked whether they would be willing to participate in a follow-on study about landscape values. Thirty consented, and on September 12, 2008, we sent each a custom-designed disposable camera with 27 exposures and a small notepad. Their instructions were to photograph 'significant' features of their farm landscape, especially those that influenced their farm management decisions, and record what they captured and why. They were asked to capture only one significant item per photograph, but - as will be discussed later - most did not. We requested that they use up at least 16 of the exposures, and invited them to take duplicates of particularly important features or capture large objects by using sequences of adjoining photos. We also provided a reply-paid envelope, and 25 cameras were returned in them between September 24 and November 21 . We had double sets of photographs developed from each camera, as well as digital scans of each image. One set of photographs we gave to the landholder 
Table 1

Popularity of targets in the photo-elicitation exercise. Shaded targets comprised $63 \%$ of all targets, and were analysed in depth qualitatively.

\begin{tabular}{|c|c|c|c|}
\hline Target classification & Number of times captured & Percent of targets & Number of graziers \\
\hline $\begin{array}{l}\text { Sparse or dead woody vegetation (inc. isolated and scattered } \\
\text { paddock trees, and riparian vegetation) }\end{array}$ & 145 & $16 \%$ & 24 \\
\hline $\begin{array}{l}\text { Ground cover species (native and non-native, perennial and } \\
\text { annual, wildflowers, reeds/water plants, understorey shrubs, } \\
\text { weeds) }\end{array}$ & 113 & $12 \%$ & 23 \\
\hline Regeneration (natural and planted) & 105 & $11 \%$ & 23 \\
\hline Paddocks (cultivated and grazed) & 91 & $10 \%$ & 22 \\
\hline $\begin{array}{l}\text { Dense woody vegetation (small and large patches, woodland } \\
\text { remnants) }\end{array}$ & 70 & $8 \%$ & 22 \\
\hline $\begin{array}{l}\text { Farm infrastructure (e.g. sheds, silage, troughs, dogs, hives, } \\
\text { access, pipes, utilities, yards, fences, equipment) }\end{array}$ & 57 & $6 \%$ & 16 \\
\hline Landscape views (holistic) & 54 & $6 \%$ & 18 \\
\hline Erosion, salinity and contour banks & 51 & $6 \%$ & 18 \\
\hline Livestock (sheep and cattle) & 45 & $5 \%$ & 17 \\
\hline Natural hydrology (marshes, rivers, springs) & 42 & $5 \%$ & 14 \\
\hline $\begin{array}{l}\text { Homesteads and gardens (inc. gates and recreation sites like } \\
\text { tennis courts) }\end{array}$ & 39 & $4 \%$ & 17 \\
\hline Farm dams & 35 & $4 \%$ & 16 \\
\hline Geology, topography, and soil & 25 & $3 \%$ & 10 \\
\hline Animals and insects (feral and native) & 17 & $2 \%$ & 8 \\
\hline Family and community (individuals and sites) & 12 & $1 \%$ & 5 \\
\hline Artefacts (indigenous, old homesteads, old farm infrastructure) & 11 & $1 \%$ & 7 \\
\hline Weather (e.g. rain) & 1 & $0.1 \%$ & 1 \\
\hline Total & 915 & $100 \%$ & 25 \\
\hline
\end{tabular}

that captured them, with the negatives, consistent with an agreement signed by both parties asserting the landholders' retention of copyright. We kept the second set, and the digital files.

We numbered our set of each landholder's photographs and used them as prompts in recorded interviews held on their properties between October 6 and December 9, 2008. Landholders were asked why they had taken each photo, with follow-ups for clarification only. There were no pre-set questions. We annotated each photo to identify individual targets as they were discussed, if ambiguous. Photograph capture locations and the directions faced were also marked on a property map supplied by the researcher, and used in a visibility analysis discussed elsewhere (Sherren et al., in press). Interview length depended on landholder personality, and ranged from 30 to $106 \mathrm{~min}$. Once interviews were transcribed and edited to remove asides and personal content, images were inserted at appropriate locations in the transcript and sent to the landholder so that they could make any desired changes. Only eight did so.

\section{Data analysis}

We decided to design our database to accommodate the way the landholders used the cameras, rather than forcing choices or otherwise limiting the dataset. This necessitated a lengthy preprocessing stage. Where the same specific feature was captured more than once, or more than one photo was used to create a panorama, we grouped photographs together. Then, individual features discussed in each photograph or photograph assemblage were identified and classified to a single descriptive target class (e.g. woody vegetation, family, farm infrastructure). If the same specific feature was captured multiple times, we also noted the number of individual pictures in the assemblage in which it appeared. We used this feature instance count, rather than counts of photographs or unique features, to assess target popularity. Finally, narratives were linked to the feature that could be said to have elicited it, allowing us to analyse the kinds of narratives elicited by various target classes.

Two different analyses were performed for this article. First, the frequency with which a target was captured was interpreted to indicate overall popularity. If landholders used their limited set of exposures to capture the same thing twice, we counted it twice. The second and more substantial analysis comprised the coding of narratives evoked by common targets. We used NVivo (QSR International Pty Ltd., 1999-2009) to separately code the narratives elicited by four popular targets and generate a separate set of themes for each.

During the coding process we parsed each narrative into its component themes, and we used a quantitative approach to decide what themes were significant. Significant themes were those volunteered by more than $20 \%$ of participating graziers (i.e. 5, a criterion also used by Kirkpatrick et al., 2007). This criterion helped to filter out the noise inherent to such data. Our analysis aimed to 'reconstitute' these significant themes into a coherent story.

\section{Results}

Woody vegetation, whether dead, mature or seedling, comprised $35 \%$ of photo targets (Table 1 ). Having participated in the ecological study, all participants were aware that vegetation was of particular interest to the researchers. However, although some contamination was possible (see Discussion), the diversity of features captured (Table 1 ) suggests that participants did not consider themselves limited to trees.

The narratives analysed here were elicited by photographs of: (1) woody vegetation (dead, sparse and dense); (2) regeneration

Table 2

Popularity of various woody vegetation structures as photo-elicitation targets.

\begin{tabular}{llcc}
\hline Structure & Target & \# Targets & \# Graziers \\
\hline Sparse & Isolated paddock trees & 50 & 19 \\
Dead & Dead trees or downed timber & 37 & 14 \\
Sparse & Scattered trees & 34 & 13 \\
Dense & Patches of trees & 29 & 14 \\
Sparse & Riparian vegetation & 24 & 9 \\
Dense & Woodlands or scrub & 23 & 9 \\
Dense & Remnant (never cleared) & 18 & 10 \\
& Total & 215 & 25 \\
\hline
\end{tabular}




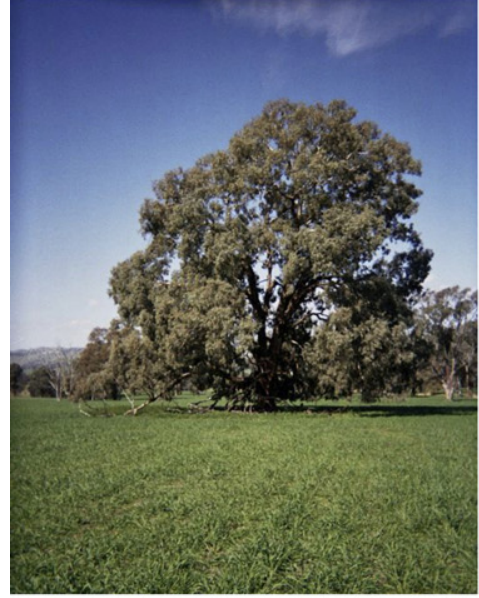

Male: A big old yellow box. He's a beauty. He's a cracker. I think there's got to be water under the ground the way that tree is - he's done so well. ...I've taken an agent down there and l've said that's my favourite tree in the place and these two blokes looked at me like I was a bloody idiot. ...I don't know how many blokes have favourite trees. (Landholder 8, photo 17)

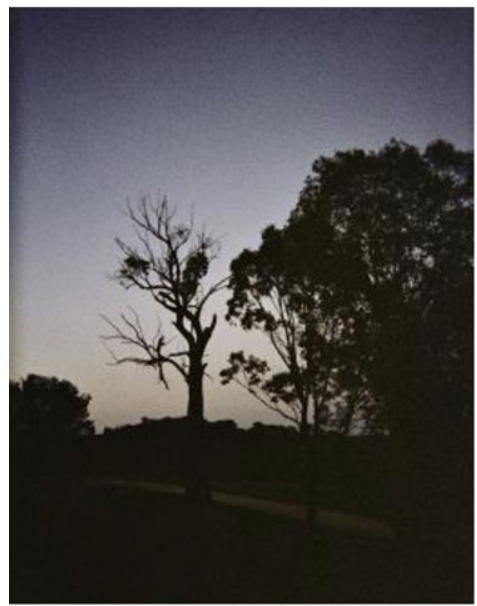

Male: I've called that Old Timer. I wrote a poem about that tree, because that tree when we came here was something like that tree [next to it] and it is basically coming to the end of its life. I've looked at that tree over the years and you know, it's basically mirroring me a bit. It's getting old and grey looking now. ... So, yes, that particular tree... is very special. (Landholders 25 , photo 22)

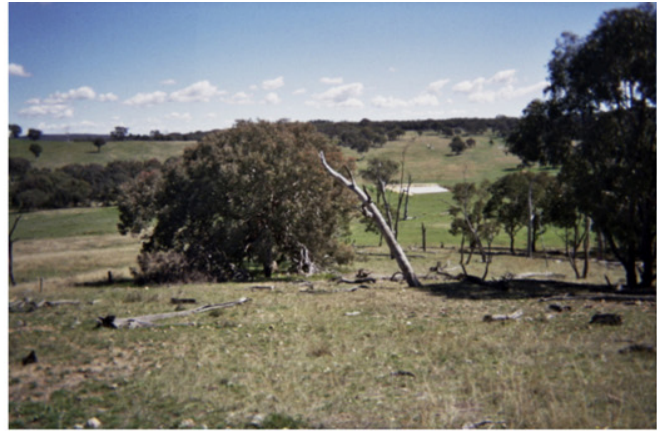

Male: I just love this tree. It's just scraggly - but it's just a beauty. ... It's just such a good shade tree. You can see a family of animals of whatever sort just under there and they could spend a hot day sitting under there chatting away to one another. ... You've actually got to walk to it because it's up on the edge of a slope. But it just lightens my heart when I see it. (Landholder 13, photo 14)

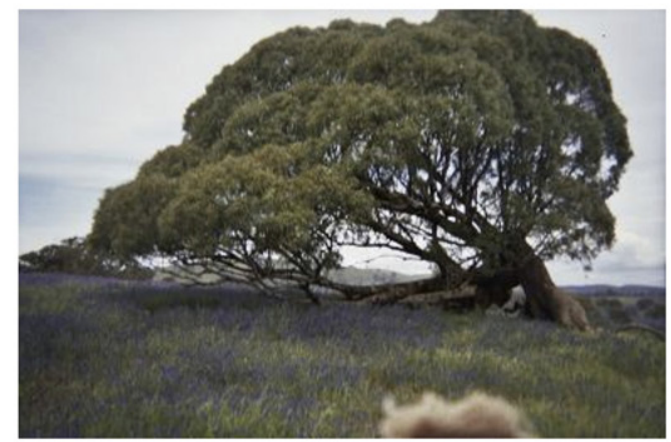

Male: I think it's a white box. It's funny, it's been caught in a windstorm and twisted and blown and all gnarly, but it's still very healthy. An interesting tree really. Hence the twig is bent, so the tree grows. ... A favourite tree. I have a lot of favourite trees. (Landholder 18, photo 12)

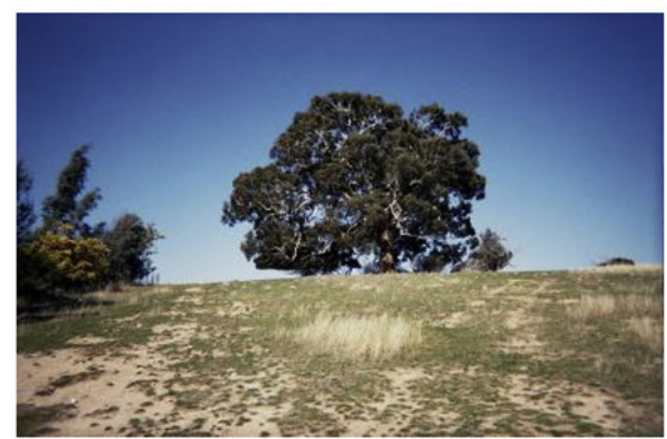

Male: That is THE tree on the place that one. It's, what do they call it? Iconic. It's just beautiful. I've heard people say, its 300 or 400 years [old]. I don't know how they know that, all I know is it's been there for - dad said it was always a big old tree like that. He was born 1909. ... It's really, really healthy. (Landholders 30 , photo 18)

Fig. 2. Some 'favourite trees' captured by participating landholders, with quotes. 
Table 3

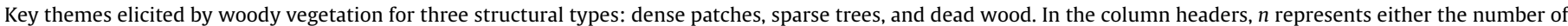

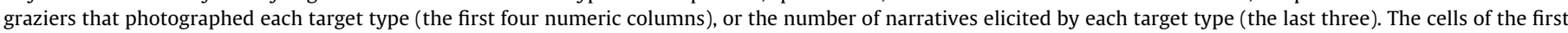

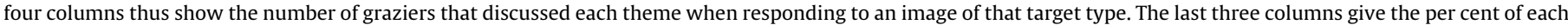
target type's narratives that expressed that theme. These do not sum to $100 \%$, as multiple coding was possible. Blank cells are zeros.

\begin{tabular}{|c|c|c|c|c|c|c|c|}
\hline \multirow[t]{2}{*}{ Theme commonly elicited } & \multicolumn{4}{|c|}{ Number of graziers discussing theme } & \multicolumn{3}{|c|}{ Percent of narratives elicited } \\
\hline & Any $n=25$ & Patch $n=22$ & Sparse $n=22$ & Dead $n=14$ & Patch $n=109$ & Sparse $n=163$ & Dead $n=44$ \\
\hline Past or present activities by self & 25 & 20 & 14 & 9 & $33.9 \%$ & $16.6 \%$ & $40.9 \%$ \\
\hline Protecting & 14 & 12 & $5^{a}$ & & $21.1 \%$ & $3.7 \%$ & \\
\hline Retaining coarse woody debris & 11 & & 4 & 8 & $0.0 \%$ & $2.5 \%$ & $27.3 \%$ \\
\hline Grazing & 11 & 8 & 7 & & $7.3 \%$ & $4.3 \%$ & \\
\hline Planting & 9 & 2 & $5^{\mathrm{a}}$ & 2 & $1.8 \%$ & $3.1 \%$ & $4.5 \%$ \\
\hline Removing coarse woody debris & 5 & 1 & 2 & 2 & $0.9 \%$ & $1.2 \%$ & $9.1 \%$ \\
\hline Intentions and planned activities & 11 & 9 & 5 & 0 & $11.9 \%$ & $4.3 \%$ & $0.0 \%$ \\
\hline Actively plant trees & 6 & 4 & 2 & & $3.7 \%$ & $1.2 \%$ & \\
\hline Encourage natural regrowth & 5 & 3 & 2 & & $2.8 \%$ & $1.2 \%$ & \\
\hline Economic issues & 14 & 7 & 10 & 0 & $8.3 \%$ & $8.6 \%$ & $0.0 \%$ \\
\hline Agency sponsorship & 7 & 5 & $3^{a}$ & & $5.5 \%$ & $1.8 \%$ & $0.0 \%$ \\
\hline Financial stricture or profit margins & 5 & 2 & 3 & & $1.8 \%$ & $2.5 \%$ & $0.0 \%$ \\
\hline Benefits & 24 & 15 & 21 & 12 & $34.9 \%$ & $39.3 \%$ & $47.7 \%$ \\
\hline Provides biodiversity benefits & 16 & 5 & 9 & 8 & $5.5 \%$ & $10.4 \%$ & $27.3 \%$ \\
\hline Beautiful & 14 & 2 & 13 & 2 & $1.8 \%$ & $12.9 \%$ & $4.5 \%$ \\
\hline Landholder emotional well-being & 12 & 4 & 7 & 3 & $3.7 \%$ & $5.5 \%$ & $6.8 \%$ \\
\hline Stock protection & 11 & 4 & 8 & & $4.6 \%$ & $5.5 \%$ & \\
\hline 'Likes' (no other information given) & 9 & 5 & 5 & 1 & $6.4 \%$ & $3.1 \%$ & $2.3 \%$ \\
\hline Connectivity for wildlife & 5 & 3 & 3 & 1 & $2.8 \%$ & $1.8 \%$ & $2.3 \%$ \\
\hline Costs & 10 & 5 & 4 & 2 & $5.5 \%$ & $2.5 \%$ & $4.5 \%$ \\
\hline Encourages pests & 4 & 3 & & 1 & $2.8 \%$ & & $2.3 \%$ \\
\hline Properties or state & 25 & 18 & 21 & 6 & $27.5 \%$ & $50.9 \%$ & $27.3 \%$ \\
\hline Aging & 13 & 1 & 11 & 2 & $0.9 \%$ & $9.2 \%$ & $4.5 \%$ \\
\hline Regenerating naturally & 13 & 10 & 5 & 1 & $10.1 \%$ & $3.7 \%$ & $2.3 \%$ \\
\hline Healthy and fertile & 11 & 2 & 9 & & $1.8 \%$ & $6.1 \%$ & \\
\hline Native tree species & 9 & 5 & 8 & & $5.5 \%$ & $7.4 \%$ & \\
\hline Not regenerating & 9 & 2 & 7 & 1 & $1.8 \%$ & $4.9 \%$ & $2.3 \%$ \\
\hline Dense or adequate cover & 7 & 2 & 5 & & $1.8 \%$ & $3.7 \%$ & \\
\hline Unhealthy & 6 & & 6 & & & $8.0 \%$ & \\
\hline Sparse or inadequate cover & 6 & 1 & 5 & 1 & $0.9 \%$ & $4.9 \%$ & $2.3 \%$ \\
\hline Mistletoe presence & 6 & 1 & 4 & 1 & $0.9 \%$ & $3.1 \%$ & $4.5 \%$ \\
\hline Burned & 3 & & & 3 & & & $6.8 \%$ \\
\hline Landholder attitudes and beliefs & 20 & 10 & 15 & 7 & $14.7 \%$ & $28.8 \%$ & $31.8 \%$ \\
\hline Native woody vegetation is declining & 11 & 3 & 9 & 4 & $2.8 \%$ & $14.1 \%$ & $20.5 \%$ \\
\hline Nutrients inhibit tree health/regeneration & 5 & 2 & 3 & & $0.9 \%$ & $2.5 \%$ & \\
\hline Heterogeneity and untidiness is good & 4 & 1 & 2 & 2 & $1.8 \%$ & $1.8 \%$ & $4.5 \%$ \\
\hline Areas poor for agriculture are protected & 4 & 2 & 2 & & $1.8 \%$ & $1.2 \%$ & \\
\hline Regeneration can occur under grazing & 3 & 1 & 3 & & $0.9 \%$ & $1.8 \%$ & \\
\hline Tree decline affects wildlife & 3 & 1 & 1 & 1 & $0.9 \%$ & $0.6 \%$ & $4.5 \%$ \\
\hline Tree age profiles cause a lag in habitat & 3 & & 3 & & & $1.8 \%$ & \\
\hline
\end{tabular}

${ }^{\text {a }}$ Largely the result of classifying riparian vegetation as sparse, as streams were commonly fenced and planted.

(natural and planted); (3) paddocks and ground cover; and, (4) landscape views (comprising $63 \%$ of all targets, shown shaded in Table 1). These target classes were chosen for their relevance to the recommended management practices for conserving tree cover presented in Introduction: managing for the survival of existing scattered trees, planting new ones, protecting naturally regenerated seedlings, reducing fertiliser use, and grazing rotationally. For brevity, numeric values presented in tables are not restated where discussed in the text.

\section{Woody vegetation}

All landholders captured woody vegetation, and the higher the density or vigour of the vegetation in question, the lower its popularity (Table 2). Isolated paddock trees were the most commonly photographed woody vegetation type, and even dead and scattered trees came above tree patches. Narratives elicited from pictures of dense tree patches, sparse trees, and dead trees were coded together to create a common set of themes. Table 3 shows that the dominant themes varied depending on the type of woody vegetation being discussed. For instance, fourteen graziers out of the 25 who photographed woody vegetation discussed protecting it, but this was more common for patches (12 graziers, and $21.2 \%$ of narratives elicited by patches) than sparse trees ( 5 graziers, and $3.7 \%$ of narratives elicited by sparse trees).

Despite sparse trees being popular targets, tree patches elicited twice as much discussion of management activities and by more graziers (Table 3 ). Tree patches most often elicited narratives about protection (Table 3 ). The management activity overwhelmingly mentioned for dead standing or fallen timber was retaining coarse woody debris. By contrast, sparse vegetation was most commonly noted as being grazed. Interestingly, most of the specific stories about grazing activities in either patches or sparse trees described natural regeneration or increases in tree health under rotational grazing.

Agency sponsorship was the most common economic issue raised, usually financial assistance in fencing patches and woodlands to exclude areas from grazing. The few times agency 
Table 4

Key themes elicited by tree regeneration.

\begin{tabular}{|c|c|c|c|}
\hline Category & Theme commonly elicited & Number of graziers $n=23$ & Percent of narratives $n=159$ \\
\hline \multirow[t]{3}{*}{ Natural } & Origin of regeneration & 15 & $20.8 \%$ \\
\hline & Stock exclusion/avoidance & 7 & $6.3 \%$ \\
\hline & Rotational grazing & 5 & $3.8 \%$ \\
\hline \multirow[t]{16}{*}{ Planted } & Method used & 16 & $27.0 \%$ \\
\hline & Seeding & 9 & $11.3 \%$ \\
\hline & Not specified & 7 & $9.4 \%$ \\
\hline & Tube stock & 9 & $6.9 \%$ \\
\hline & Structure or location & 18 & $28.9 \%$ \\
\hline & Linear strip & 15 & $20.1 \%$ \\
\hline & Around water body & 8 & $8.2 \%$ \\
\hline & Cause for success & 16 & $20.1 \%$ \\
\hline & Stock exclusion & 9 & $8.8 \%$ \\
\hline & Rationale or benefits & 17 & $30.8 \%$ \\
\hline & Provide habitat & 9 & $6.9 \%$ \\
\hline & Improve soil stability & 7 & $8.2 \%$ \\
\hline & Heal salinity & 5 & $3.1 \%$ \\
\hline & Attractive & 5 & $3.8 \%$ \\
\hline & Disbenefits & 4 & $5.7 \%$ \\
\hline & Looks and behaves unnaturally & 3 & $4.4 \%$ \\
\hline \multirow[t]{7}{*}{ Landholder-specific } & Financial or emotional issues & 16 & $18.2 \%$ \\
\hline & Agency sponsorship & 10 & $10.1 \%$ \\
\hline & Landholders bearing costs & 8 & $6.3 \%$ \\
\hline & Pride & 5 & $3.7 \%$ \\
\hline & Management intentions or desires & 8 & $6.3 \%$ \\
\hline & Do more planting & 3 & $2.5 \%$ \\
\hline & Reintegrate in grazing rotation when safe & 4 & $2.5 \%$ \\
\hline
\end{tabular}

sponsorship was mentioned in relation to sparse vegetation referred to fencing creeks to exclude stock.

Narratives elicited by woody vegetation were more frequently about its benefits (39\%) than its costs (4\%), and sparse trees inspired the widest range of benefits by the largest group of graziers (Table 3 ). Although tree patches are the most often protected of the structures studied, images of dense vegetation inspired less agreement about their benefits, with a maximum of five graziers nominating any one theme; a generic appreciation was the most commonly expressed. Consistent with the dominance of retaining coarse woody debris, the most common benefit noted for dead wood was habitat for biodiversity. Habitat was a common benefit noted for sparse vegetation, too, but even more prevalent was aesthetic beauty, a characteristic rarely ascribed to tree patches. Stock protection was also commonly cited as a benefit of sparse trees, and their contribution to landholder well-being, including confessions of 'favourite trees' (Fig. 2), and stories of family picnic spots, bird-watching, and the satisfactions derived from stewardship.

Some themes related to the properties of the targeted vegetation. Images of dead vegetation did not inspire much description (Table 3). Images of tree patches were mostly described as regenerating naturally, or comprised of native trees. In contrast, half of the narratives elicited by sparse vegetation were descriptions. Half of those who photographed sparse vegetation noted that it was aging. Many also noted the native species within. Descriptions sometimes appear contradictory: roughly equal numbers and proportions of narratives identified sparse structures as healthy and unhealthy, and as demonstrating inadequate or adequate cover. However, mentions of mistletoe and a lack of natural regeneration also suggest sparse trees were seen as suffering.

In addition to the above deconstructive themes, we also identified twenty common relationships and concepts present in the narratives elicited by woody vegetation (Table 3 ). By far the most common was that native woody vegetation is declining, and most of the graziers made such comments in relation to sparse trees. A few graziers observed how the age gap in the remaining scattered trees will cause a lag time in recovery, potentially disastrous for the animals that depend on them.

\section{Regeneration}

Narratives about tree planting received more attention in interviews than natural regeneration. Natural regeneration targets were most commonly described in terms of their perceived origin, typically stock exclusion or at least avoidance (Table 4). A further five graziers, all practicing rotational grazing, recounted how their rotation regime inspired natural tree recruitment under grazing. Very little discussion was made, and certainly no consensus expressed, about the costs or benefits of natural regeneration or the causes for its failure.

Tree plantings were also described in a range of ways (Table 4). Most significant was the dominance of plantings arranged linearly along fence lines or contour banks, so common that its amount was often discussed in terms of length, rather than area. Plantings were also described as being near water bodies or wet areas, and some of these plantings would also likely be linear in structure. The seed mixes used tended to include a higher proportion of flowering trees and understorey shrubs than found elsewhere on the property, and the resulting species mix and density was sometimes described as 'unnatural'. Spatial arrangements and floristic composition were consistent with the main reasons graziers volunteered for planting: improving soil stability and habitat, primarily for birds. Stock exclusion was the most common reason given for the survival of tree plantings.

Agency sponsorship was the most common landholder issue elicited by images of regeneration (Table 4 ). For instance, agencies often supply the seed mixes. Landholders bear some costs of regeneration themselves, and certainly experience opportunity costs in 
Table 5

Key themes elicited by paddocks and ground cover.

\begin{tabular}{|c|c|c|}
\hline Theme commonly elicited & Number of graziers $n=25$ & Percent of narratives $n=281$ \\
\hline Description & 25 & $54.1 \%$ \\
\hline Undesirable forage species (unproductive, weeds) & 14 & $14.2 \%$ \\
\hline Native pasture species & 14 & $8.2 \%$ \\
\hline Productive (good, dense, desirable species) & 14 & $6.8 \%$ \\
\hline Sparse, bare or overgrazed & 12 & $7.1 \%$ \\
\hline Diverse, complex or heterogeneous & 10 & $5.0 \%$ \\
\hline Non-native/exotic pasture species & 8 & $7.1 \%$ \\
\hline Recovering & 7 & $4.6 \%$ \\
\hline Perennial pasture species & 6 & $3.2 \%$ \\
\hline Activities & 20 & $38.4 \%$ \\
\hline Rotational grazing or holistic management & 13 & $5.7 \%$ \\
\hline Treatments (lime, fertiliser, spray weeds and pests) & 12 & $8.5 \%$ \\
\hline Sowing (for grain, forage, silage, etc.) & 10 & $14.9 \%$ \\
\hline Subdividing paddocks & 6 & $2.5 \%$ \\
\hline Conservation work (e.g. planting trees) & 5 & $2.1 \%$ \\
\hline Using stock to mulch and fertilise soil & 5 & $1.8 \%$ \\
\hline Ceased cropping & 4 & $2.5 \%$ \\
\hline Landholder attitudes and beliefs & 20 & $25.6 \%$ \\
\hline Diversity of ground cover brings resilience & 8 & $6.8 \%$ \\
\hline Rotational grazing has multiple benefits & 8 & $5.7 \%$ \\
\hline Native pastures are most desirable (e.g. resilient) & 7 & $2.8 \%$ \\
\hline Ploughing is damaging to the land base & 7 & $2.8 \%$ \\
\hline Cropping has lingering negative impacts & 7 & $2.5 \%$ \\
\hline Management issues & 17 & $14.2 \%$ \\
\hline Impact of weather (e.g. drought, frost) & 8 & $5.0 \%$ \\
\hline Financial risks in adopting recommended practices & 6 & $2.1 \%$ \\
\hline Climate change (e.g. ‘drought proofing’, carbon) & 5 & $2.8 \%$ \\
\hline
\end{tabular}

the labour they provide in-kind. Financial support from agencies appears of paramount importance to graziers in inspiring regeneration activities and even reducing their clearing. One said, of his recent bid to a conservation program, that "I thought it might be better just to leave it and get paid for it, rather than clear it" (Landholder 26).

\section{Paddocks and ground cover}

Images of paddocks and ground cover elicited a large set of narratives, representing a great diversity of management practices (Table 5). Most prominent were descriptions, noting the desirable or undesirable ground cover species, and its condition (e.g. overgrazed, recovering). Native pasture species were more commonly pointed out than exotics, and perennials were specifically identified more than annuals. Natives were frequently discussed in terms of their suitability for drought-prone settings. Many, especially rotational graziers, also noted that having a diversity of cover types brings them resilience - even weeds if the alternative is bare ground.

While a handful of landholders spoke of having ceased cropping activities, and more about the ground cover problems that lingered in paddocks that had once been cropped, many landholders are still sowing in order to thicken pastures or produce silage for dry times or for sale (Table 5). Pest and weed spraying, and soil fertility and chemistry treatments remain common. Ploughing is very rarely done, however; most sowing was described as 'direct drilled', and ploughing was discussed in terms of degrading the land base and leaving it vulnerable when bare.

Rotational grazing is unlikely to be as prominent a practice sector-wide as it appears in Table 5 (Richards and Lawrence, 2009); those undertaking continuous grazing rarely mentioned it (Kirkpatrick and Bridle, 2007, found similarly). Rotational graziers were quite enthusiastic about their practices, such as subdividing paddocks and using stock to mulch and fertilise the soil, and the multiple benefits of those practices (see also Greiner et al., 2008).
Nonetheless, some landholders volunteered challenges to adopting rotational grazing and reducing fertiliser use, such as the cost of splitting paddocks and changing to perennial pastures, and water supply problems in small paddocks.

\section{Landscape views}

Narratives elicited by holistic landscape images demonstrated little consensus. Consistent with the popularity of woody vegetation in the overall exercise, the most common features identified in such images were trees (Table 6). No other features were pointed out by more than four landholders. Most of those discussing landscape views found them beautiful, and five also noted their agricultural utility.

Several common attitudes or concepts were also evident by the discussions elicited by landscape views (Table 6). Most common

Table 6

Key themes elicited by landscape views.

\begin{tabular}{lrr}
\hline Theme commonly elicited & \# Graziers $n=18$ & \% Narratives $n=79$ \\
\hline Targeted features & 14 & $40.5 \%$ \\
$\quad$ Woody vegetation & 8 & $10.8 \%$ \\
Characteristics & 15 & $39.2 \%$ \\
$\quad$ Beautiful & 14 & $28.4 \%$ \\
$\quad$ Good utility (productive) & 5 & $6.8 \%$ \\
Landholder attitudes & 11 & $35.1 \%$ \\
$\quad$ Can integrate & 5 & $9.5 \%$ \\
$\quad$ conservation and & & \\
$\quad$ production & 4 & $6.8 \%$ \\
Landscape quality and & & \\
$\quad$ health affects mood & 7 & $9.5 \%$ \\
Reason for capture & 4 & \\
Shows area of & & \\
$\quad \begin{array}{l}\text { ownership, or used to } \\
\text { assess farm status }\end{array}$ & & \\
Emblematic of farm & 4 & \\
$\quad$ activities/routines & &
\end{tabular}


was the idea that conservation and production can be integrated, even without tradeoffs. Rotational graziers were most likely to volunteer this opinion. A few graziers also volunteered how landscape quality or health affects their mood.

\section{Discussion}

Simple counts of the targets captured in this photo-elicitation exercise suggest that graziers ascribed great significance to the woody vegetation in their working landscapes (Table 1). As mentioned earlier, however, the graziers who participated in this study were also involved in a linked ecological experiment focussed on tree survival under grazing; there is some risk that the graziers therefore were inclined to capture trees because of this experience. Such a possibility is difficult to disprove entirely, but there are indications that the significance of woody vegetation is real, rather than just an artefact reflecting our sample of graziers. First, the diversity of targets landholders captured suggests they did not feel limited in their choices (Table 1). Indeed, when the issue of bias was raised in relation to this data at a stakeholder workshop in June 2009 that many of the graziers attended, they expressed uniform surprise at the possibility of bias having interfered in their choices. Second, a catchment-scale landholder survey we ran in 2008 showed that three-quarters of those surveyed valued trees on their farms for a range of production, ecosystem and cultural services (Sherren et al., in press). Finally, a preference for trees is consistent with past work on landscape aesthetics involving the general population, in which trees were typically judged as important components of scenic landscapes (see, for instance, Arriaza and Canas-Ortega, 2004; Hagerhall et al., 2004; Nassauer, 1995; Ode et al., 2009; Purcell and Lamb, 1998; Rogge et al., 2007; Wu et al., 2006). On this basis, we feel confident that the appreciation for trees that graziers demonstrated in this study is genuine, and that it may indeed be indicative of a more general attachment to trees in the wider grazier community.

Target popularity also suggests that sparse vegetation was valued by graziers more than vegetation in patches (Table 2). We know that $90 \%$ of our landscape has only isolated or scattered vegetation (Fischer et al., 2009a), so it is possible that the preference for sparse trees evident here is simply an indicator of relative presence. However, four arguments suggest that scattered (rather than dense) trees are indeed particularly popular, consistent with their disproportionate environmental contribution (Fischer et al., 2009a). First, a visibility analysis of the same target data showed that isolated and scattered trees were captured 2.2 and 1.7 times more than would be suggested by simple opportunity, whereas woodlands were not captured more than expected (Sherren et al., in press). Second, aesthetics often drive photographic choices, and while all trees contributed positively to graziers' assessments of the beauty of their farm landscapes (Table 6), they saw sparse trees as supplying more of this quality than patches (Table 3 ). In fact, beauty was the most common theme elicited overall for sparse trees. Third, sparse trees are an iconic part of the Australian farming landscape. They are seen as survivors - 'battlers' - and somehow emblematic of the Australian character; the drama they contribute to a landscape is all the more poignant for their decline. Farmers are proud to foster these icons: all of the 'favourite' trees our graziers volunteered were isolated ones (Fig. 2). Finally, other researchers have hypothesized that an intermediate level of vegetation cover is preferred by humans for evolutionary purposes: it is easier to see both prey and predators (Kaplan, 1987).

Graziers appear to be aware of the decline of sparse trees in grazing settings resulting from aging, poor health and a lack of natural regeneration. This is evident from landholders' descriptions of sparse vegetation images, and by how often those images elicited explicit concerns about tree decline (Table 3). This is consistent with our recent landholder survey that found $45 \%$ of survey respondents had noticed decreases in their isolated trees, compared with $19 \%$ or less who noticed declines in other vegetation arrangements (Sherren et al., in press). Despite such awareness and concern about sparse trees, only patches were being managed for conservation (Table 3). Isolated and scattered trees were rarely being protected or intentionally planted; only one grazier mentioned having done the latter (Table 4). Instead, linear plantings were being 'substituted' for losses elsewhere (Table 4). Such practices will result in the further consolidation of tree cover into protected patches - likely in upland areas unsuitable for agriculture (Fischer et al., 2009a) surrounded by paddocks devoid of scattered trees and their many services. Integrating conservation and production activities is the most promising way to restore and maintain landscape-scale heterogeneity (Fischer et al., 2008, 2009a).

Education and incentive programs have an important role to play in future, as they appear from our research to have had in the past. Prominent themes elicited by images of dead wood, woodlands, revegetation sites and ground cover reflect existing education and incentive programs. For instance, consistent with various acts of legislation (Australian Government, 1999; New South Wales Government, 1995) and education campaigns since the 1990s (e.g. Landcare), graziers reported leaving dead wood on the ground because of its importance for biodiversity (Vesk and MacNally, 2006). Similarly, as encouraged by a range of government initiatives, graziers have fenced many of their woodlands and described them to us as regenerating naturally. The design of such initiatives, such as incentives that fund permanent rather than temporary fencing, has encouraged the permanently stock-free fence line plantings that featured so frequently in graziers' photographs (see also Bennett et al., 2000; Ticehurst et al., 2009). Finally, graziers reported practicing no-till cultivation perhaps because of at least four decades of agricultural research and extension (Coughenour and Chamala, 2000; Oliver et al., 2009). In summary, our data clearly demonstrated that conservation messages and incentives about some vegetation structures have been successful at reaching their targets.

Integrating conservation and production is not commonly a guiding principle in the design of education and incentive programs related to vegetation management. Some of the possible components have already been discussed: managing for the survival of existing scattered trees, planting new ones, protecting naturally regenerated seedlings, reducing fertiliser use, and grazing rotationally (Fischer et al., 2009b). Some of these are quite challenging ideas. For instance, narratives elicited by photographs of regeneration reveal the widespread belief that regeneration only succeeds under stock exclusion, and that protection is the best way to manage valued tree cover (Table 4). There were exceptions, however. Some graziers described increases in tree health or natural regeneration under high-intensity, short-duration rotational grazing, consistent with our scientific analyses (Fischer et al., 2009b). Those grazing rotationally were also most likely to mention reintegrating planted areas back into a grazing rotation, rather than sacrificing them permanently (Table 4). This suggests that conservation and production were not seen as mutually exclusive by this group of graziers (see also Stinner et al., 1997). Fertiliser is also a difficult issue, because a complete cessation of its use - ideal for native trees ill-adapted to high nutrients - may render Australia's 'old soils' economically unviable. While many landholders described how native pasture species need less fertiliser and are more adapted to Australian conditions, they still often preferred a mixture because they saw natives as lacking the productivity of exotic species (Table 6). Further innovation is required to design farming systems that can 
co-exist with native vegetation, and flexible policy settings that encourage adaptability.

Finally, if an inclination towards maintaining and protecting trees exists among graziers at present, it may not necessarily be able to survive under future conditions. For instance, numerous market and climate pressures are leading graziers to undertake increasing amounts of cropping (Sherren et al., in press). The large equipment and practices like centre-pivot irrigation and GPS-guided machinery used in cropping directly threaten scattered trees (Gibbons et al., 2009; Maron and Fitzsimons, 2007). Education alone may never be enough to conserve scattered tree cover in this context, and policies may have to rely more on regulation than incentives in order to maintain tree cover.

\section{Conclusions}

Photo-elicitation exposed the deeply held personal conceptions of landholders that drive grazing practices. Our study suggests support for several conclusions relevant to agricultural and conservation policy-makers who are seeking to encourage the retention of scattered trees in grazing country. First, graziers value their trees, especially sparse ones, for multiple practical and cultural reasons. Second, graziers are aware of and concerned about the decline in their sparse trees, and the risks that decline holds for them and the public good. Third, graziers are receptive to education campaigns and incentive programs that are aimed at shaping their management practices. Fourth, graziers do not appear to know how to maintain their scattered trees, or lack incentives to do so.

At present there is a lack of clear messages about scattered trees, their benefits, and appropriate management approaches, and there are no incentives for their active management. This presents a challenge, but also a policy opportunity. Maintaining scattered tree cover requires providing clear recommendations on how to do so, as well as incentives that are low-risk and can be adapted to local conditions. Policy settings must be urgently expanded to target the maintenance of landscape-scale scattered tree cover, and thus protect the complementary values provided by scattered trees for grazing operations, graziers and ecosystem function.

\section{Acknowledgements}

This work was funded by the Australian Research Council and the Australian Government Department of Environment, Water, Heritage and the Arts, the latter through a Commonwealth Environment Research Facilities 'Significant Project'. The Australian National University Human Research Ethics Committee approved our methodology as adhering to the National Statement on Ethical Conduct in Human Research. The authors thank the landholders and other stakeholders who have collaborated in this work. Thanks also go to Jenny Stott and Jerome Pink for skilled and valued research assistance.

\section{References}

Anastasi, A., 1988. Psychological Testing. Macmillan, New York, NY, 721 pp. Arler, F., 2000. Aspects of landscape or nature quality. Landscape Ecology 15 291-302.

Arriaza, M., Canas-Ortega, J.F., 2004. Assessing the visual quality of rural landscapes. Landscape and Urban Planning 69, 115-125.

Australian Government, 1999. The Environment Protection and Biodiversity Protection Act. Department of the Environment Water Heritage and the Arts. Attorney-General's Department, Canberra, ACT

Bardsley, P., Chaudhri, V., Stoneham, G., Strappazzon, L., 2002. New directions in environmental policy. Agenda 9,1-12.

Beckley, T.M., Stedman, R.C., Wallace, S.M., Ambard, M., 2007. Snapshots of what matters most: using resident-employed photography to articulate attachment to place. Society and Natural Resources 20, 913-929.
Beilin, R., 2005. Photo-elicitation and the agricultural landscape: 'seeing' and 'telling' about farming, community and place. Visual Studies 20, 56-68.

Bennett, A.F., Kimber, S.L., Ryan, P.A., 2000. Revegetation and wildlife-a guide to enhancing revegetated habitats for wildlife conservation in rural environments. In: Bushcare (Ed.), National Research and Development Program Research Report. Environment Australia, Canberra Australia and Online: http://www.environment.gov.au/land/publications/pubs/revegwild.pdf, 39 pp.

Benson, JS. Redpath, P.A. 1997. The nature of pre-European native vegetation in south-eastern Australia: a critique of Ryan, D.G., Ryan, J.R. and Starr, B.J. (1995) The Australian Landscape-Observations of Explorers and Early Settlers. Cunninghamia 5, 285-327.

Bird, P.R., Bicknell, D., Bulman, P.A., Burke, S.J.A., Leys, J.F., Parker, J.N., Van der Sommen, F.J., Voller, P., 1992. The role of shelter in Australia for protecting soils, plants and lifestock. Agroforestry Systems 20, 59-86.

Bonaiuto, M., Carrus, G., Martorella, H., Bonnes, M., 2002. Local identity processes and environmental attitudes in land use changes: the case of natural protected areas. Journal of Economic Psychology 23, 631-653.

Brodt, S., Klonsky, K., Tourte, L., 2006. Farmer goals and management styles: implications for advancing biologically based agriculture. Agricultural Systems 89, 90-105.

Byron, I., Curtis, A., MacKay, J., 2006. Benchmarking Community Attitudes Towards Natural Resource Management in the Lachlan Catchment. Australian Government Bureau of Rural Sciences, Canberra, ACT, 78 pp.

Cañas, I., Ayuga, E., Ayuga, F., 2009. A contribution to the assessment of scenic quality of landscapes based on preferences expressed by the public. Land Use Policy 26 , 1173-1181.

Cary, J.W., 1993. The nature of symbolic beliefs and environmental behaviour in a rural setting. Environment and Behaviour 25, 555-576.

Collier, J.J., 1957. Photography in anthropology: a report on two experiments. American Anthropologist 59, 843-859.

Collier, M., 2001. Approaches to analysis in visual anthropology. In: Van Leeuwen, T., Jewitt, C. (Eds.), Handbook of Visual Analysis. SAGE Publications Ltd., London, UK, pp. 35-60.

Coughenour, C.M., Chamala, S., 2000. Conservation Tillage and Cropping Innovation: Constructing the New Culture of Agriculture. Iowa State University Press, Ames, IA.

Curtis, A., De Lacy, T., 1998. Landcare, stewardship and sustainable agriculture in Australia. Environmental Values 7, 59-78.

Dalton, P., Dunnett, G., 1992. A Psychology for Living: Personal Construct Theory for Professionals and Clients. J. Wiley \& Sons, Chichester, UK

Davis, J.L., Green, J.D., Reed, A., 2009. Interdependence with the environment: commitment, interconnectedness, and environmental behaviour. Journal of Environmental Psychology 29, 173-180.

de Groot, J.I.M, Steg, L., 2008. Value orientations to explain beliefs related to environmental significant behavior. Environment and Behaviour 40, 330-354.

Dennis Jr., S.F., Gaulocher, S., Carpiano, R.M., Brown, D., 2009. Participatory photo mapping (PPM): exploring an integrated method for health and place research with young people. Health \& Place $15,466-473$.

Dettman, P.D., Hamilton, S.D., Curtis, A.L., 2000. Understanding landholder values and intentions to improve remnant vegetation management in Australia: the Box-Ironbark case study. Journal of Sustainable Agriculture 16, 93-105.

DEWHA, 2009. White box-yellow box-Blakely's red gum grassy woodland and derived native grassland. In: Australian Government Department of the Environment Water Heritage and the Arts, Species Profile and Threats Database. Online at http://www.environment.gov.au/sprat. Last accessed 14 November, 2009.

Dorrough, J., Moxham, C., 2005. Eucalypt establishment in agricultural landscapes and implications for landscape-scale restoration. Biological Conservation 123, 55-66.

Dorrough, J., Yen, A., Turner, V., Clark, S.G., Crosthwaite, J., Hirth, H.R., 2004. Livestock grazing management and biodiversity conservation in Australian temperate grassy landscapes. Australian Journal of Agricultural Research 55, 279-295.

Dramstad, W.E., Tveit, M.S., Fjellstad, W.J., Fry, G.L.A., 2006. Relationships between visual landscape preferences and map-based indicators of landscape structure. Landscape and Urban Planning 78, 465-474.

Eldridge, D.J., Freudenberger, D., 2005. Ecosystems wicks: woodland trees enhance water infiltration in a fragmented agricultural landscape in eastern Australia. Austral Ecology 30, 336-347.

Fielding, K.S., Deborah, J.T., Masser, B.M., Hogg, M.A., 2008. Integrating social identity theory and the theory of planned behaviour to explain decisions to engage in sustainable agricultural practices. British Journal of Social Psychology 47, 2348.

Fischer, A., Young, J.C., 2007. Understanding the mental constructs of biodiversity: implications for biodiversity management and conservation. Biological Conservation 136, 271-282.

Fischer, J., Brosi, B., Daily, G.C., Ehrlich, P.R., Goldman, R., Goldstein, J., Lindenmayer, D., Manning, A.D., Mooney, H.A., Pejchar, L., Ranganathan, J., Tallis, H., 2008. Should agricultural policies encourage land sparing or wildlife-friendly farming? Frontiers in Ecology and the Environment 6, 380-385.

Fischer, J., Sherren, K., Stott, J., Zerger, A., Warren, G., Stein, J., (2009a). Towards landscape-wide conservation outcomes in Australia's temperate grazing region. Frontiers in Ecology and the Environment. doi:10.1890/080170, in press.

Fischer, J., Stott, J., Zerger, A., Warren, G., Sherren, K., Forrester, R.I., 2009b. Reversing a tree regeneration crisis in an endangered ecoregion. Proceedings of the National Academy of Sciences 106, 10386-10391. 
Foley, J.A., DeFries, R., Asner, G.P., Barford, C., Bonan, G., Carpenter, S.R., Chapin, F.S. Coe, M.T., Daily, G.C., Gibbs, H.K., Helkowski, J.H., Holloway, T., Howard, E.A., Kucharik, C.J., Monfreda, C., Patz, J.A., Prentice, I.C., Ramankutty, N., Snyder, P.K., 2005. Global consequences of land use. Science 309, 570-574.

Ford, R.M., Williams, K.J.H., Bishop, I.D., Webb, T., 2009. A value basis for the social acceptability of clearfelling in Tasmania, Australia. Landscape and Urban Planning 90, 196-206.

Fransella, F., Bannister, D., 1977. A Manual for Repertory Grid Technique. Academic Press, London, UK.

Freudenberger, D., Harvey, J., Drew, A., 2004. Predicting the biodiversity benefits of the Saltshaker Project, Boorowa, NSW. Ecological Management and Restoration $5,5-14$.

Frost, F.M., 2000. Value orientations: impact and implications in the extension of complex farming systems. Australian Journal of Experimental Agriculture 40, 511-517.

Garrod, B., 2007. Exploring place perception: a photo-based analysis. Annals of Tourism Research 35, 381-401.

Germino, M.J., Reiners, W.A., Blasko, B.J., McLeod, D., Bastian, C.T., 2001. Estimating visual properties of Rocky Mountain landscapes using GIS. Landscape and Urban Planning 53, 71-83.

Gibbons, P., Briggs, S.V., Ayers, D., Seddon, J., Doyle, S., Cosier, P., McElhinny, C., Pelly, V., Roberts, K., 2009. An operational method to assess impacts of land clearing on terrestrial biodiversity. Ecological Indicators 9, 26-40.

Gibbons, P., Lindenmayer, D.B., Fischer, J., Manning, A.D., Weinberg, A., Seddon, J., Ryan, P., Barrett, G., 2008. The future of scattered trees in agricultural landscapes. Conservation Biology 22 (5), 1309-1319.

Gobster, P.H., Nassauer, J.I., Daniel, T.C., Fry, G., 2007. The shared landscape: what does aesthetics have to do with ecology? Landscape Ecology 22, 959-972.

Greiner, R., Miller, O., Patterson, L., 2008. The role of grazier motivation and risk attitudes in the adoption of grazing best management practices. In: 52nd Annual Conference of the Australian Agricultural and Resource Economics Society. Australian Agricultural and Resource Economics Society, Canberra, ACT, http://ageconsearch.umn.edu/bitstream/6002/2/cp08gr28.pdf.

Gunderson, K., Watson, A., 2007. Understanding place meanings on the Bitterroot National Forest, Montana. Society and Natural Resources 20, 705-721.

Hagerhall, C.M., Purcell, T., Taylor, R., 2004. Fractal dimension of landscape silhouette outlines as a predictor of landscape preference. Journal of Environmental Psychology 24, 247-255.

Harper, D., 2002. Talking about pictures: a case for photo elicitation. Visual Studies $17,13-26$.

Hodgkins, D., Goldney, D., Watson, G., Tyson, G., 1999. The attitudes of landholders to a range of environmental issues, including the values of remnant bushland in the central western region of New South Wales. In: Hobbs, R.J., Yates, C.J. (Eds.), Temperate Eucalypt Woodlands in Australia: Biology, Conservation, Management and Restoration. Surrey Beatty \& Sons, Chipping Norton, UK, pp. 336-350.

Hoekstra, J.M., Boucher, T.M., Ricketts, T.H., Roberts, C., 2005. Confronting a biome crisis: global disparities of habitat loss and protection. Ecology Letters 8, 23-29.

Hunziker, M., Kienast, F., 1999. Potential impacts of changing agricultural activities on scenic beauty-a prototypical technique for automated rapid assessment. Landscape Ecology 14, 161-176.

Jurin, R.R., Fortner, R.W., 2002. Symbolic beliefs as barriers to responsible environmental behaviour. Environmental Education Research 8, 373-394.

Kaplan, S., 1987. Aesthetics, affect, and cognition: environmental preference from an evolutionary perspective. Environment and Behaviour 19, 3-32.

Kirkpatrick, J., Bridle, K., 2007. People, Sheep and Nature Conservation: The Tasmanian Experience. CSIRO Publishing, Collingwood, VIC.

Kirkpatrick, J.B., Bridle, K.L., Edwards, J., Vercoe, J., 2007. Conserving on the run country. In: Kirkpatrick, J., Bridle, K. (Eds.), People, Sheep and Nature Conservation: The Tasmanian Experience. CSIRO Publishing, Collingwood, VIC.

Lal, P., Lim-Applegate, H., Scoccimarro, M.C., 2001. The adaptive decision-making process as a tool for integrated natural resource management: focus, attitudes, and approach. Conservation Ecology 5, 11.

Lawrence, G., Richards, C.A., Cheshire, L., 2004. The environmental enigma: why do producers professing stewardship continue to practice poor natural resource management. Journal of Environmental Policy and Planning 6, 251-270.

Lumsden, L.F., Bennett, A.F., 2005. Scattered trees in rural landscapes: foraging habitat for insectivorous bats in south-eastern Australia. Biological Conservation $122,205-222$.

Lunt, I.D., Jones, N., Spooner, P.G., Petrow, M., 2006. Effects of European colonization on indigenous ecosystems: post-settlement changes in tree stand structures in Eucalyptus-Callitris woodlands in central New South Wales, Australia. Journal of Biogeography 33, 1102-1115.

Manning, A., Lindenmayer, D.B., 2009. Paddock trees, parrots and agricultural production: an urgent need for large-scale, long-term restoration in south-eastern Australia. Ecological Management and Restoration 10, 126-135.

Manning, A.D., Fischer, J., Lindenmayer, D.B., 2006. Scattered trees are keystone structures-implications for conservation. Biological Conservation 132, 311-321.

Manning, A.D., Gibbons, P., Lindenmayer, D.B., 2009. Scattered trees: a complementary strategy for facilitating adaptive responses to climate change in modified landscapes? Journal of Applied Ecology 46, 915-919.

Markwell, K.W., 1997. Dimensions of photography in a nature-based tour. Annals of Tourism Research 24,131-155.
Maron, M., Fitzsimons, J.A., 2007. Agricultural intensification and loss of matrix habitat over 23 years in the West Wimmera, south-eastern Australia. Biological Conservation 135, 587-593.

McGuckian, N., Rickards, L., 2009. The social dimensions of mixed farming systems. In: Tow, P., Cooper, I., Partridge, I., Birch, C. (Eds.), Rainfed Farming Systems. Springer, New York

Meine, C., 1987. The farmer as a conservationist: Aldo Leopold on agriculture. Journa of Soil and Water Conservation 42, 144-149.

Moore, S.A., 2002. Contributions of sense of place to sustainability in agricultura landscapes. In: International Sociological Association XVth World Sociology Conference, Brisbane, Australia.

Moore, S.A., Renton, S., 2002. Remnant vegetation, landholders' values and information needs: an exploratory study in the West Australian wheatbelt. Ecological Management and Restoration 3, 179-187.

Munro, N.T., Fischer, J., Wood, J., Lindenmayer, D.B., 2009. Revegetation in agricultural areas: the development of structural complexity and floristic diversity. Ecological Applications 19, 1197-1210.

Nassauer, J.I., 1995. Messy ecosystems, orderly frames. Landscape Journal 14 161-169.

New South Wales Government, 1995. Threatened Species Conservation Act. Department of Environment and Conservation. Parliamentary Counsel's Office, Sydney NSW

Ode, Å., Fry, G., Tveit, M.S., Messager, P., Miller, D., 2009. Indicators of perceived naturalness as drivers of landscape preference. Journal of Environmental Management $90,375-383$.

Oliver, M., Ashton, D., Hodges, A., Mackinnon, D., 2009. Farmers' Use of Sustainable Management Practices. Australian Bureau of Agricultural and Resource Economics. National Land and Water Resources Audit, Canberra, ACT, 40 pp.

Ozolins, A., Brack, C., Freudenberger, D., 2001. Abundance and decline of isolated trees in the agricultural landscapes of central New South Wales, Australia. Pacific Conservation Biology 7, 195-203.

Palmer, J.F., 2004. Using spatial metrics to predict scenic perception in a changing landscape: Dennis, Massachusetts. Landscape and Urban Planning 69, 201218.

Pingjun, D., 2008. Gazing at the cradle of the duststorm: a photo story of humans and the environment in Alxa. Academy Press, Beijing, China, $111 \mathrm{pp}$.

Prosser, J., Schwartz, D., 1998. Photographs within the sociological research process. In: Prosser, J. (Ed.), Image-based Research: A Sourcebook for Qualitative Researchers. Falmer Press, London, UK, pp. 115-130.

Purcell, A.T., Lamb, R.J., 1998. Preference and naturalness: an ecological approach. Landscape and Urban Planning 42, 57-66.

QSR International Pty Ltd., 1999-2009. QSR NVivo Version 8.0.332.0 SP4.

Raymond, C.M., Bryan, B.A., MacDonald, D.H., Cast, A., Strathearn, S., Grandgirard, A. Kalivas, T., 2009. Mapping community values for natural capital and ecosystem services. Ecological Economics 68, 1301-1315

Richards, C., Lawrence, G., 2009. Adaptation and change in Queensland's rangelands: cell grazing as an emerging ideology of pastoral-ecology. Land Use Policy 26 630-639.

Rogge, E., Nevens, F., Gulinck, H., 2007. Perception of rural landscapes in Flanders: looking beyond aesthetics. Landscape and Urban Planning 82, 159-174.

Seabrook, L., McAlpine, C., Fensham, R., 2008. What influences farmers to keep trees? A case study from the Brigalow Belt, Queensland, Australia. Landscape and Urban Planning 84, 266-281.

Sherren, K., Fischer, J., Clayton, H., Schirmer, J., Dovers, S., in press. Integration by case, place and process: transdisciplinary research for sustainable grazing in the Lachlan River catchment, Australia. Landscape Ecology.

Sherren, K., Fischer, J., Pink, J., Stott, J., Stein, J., in press. Australian graziers value trees in their pastures: a viewshed analysis of photo elicitation. Society and Natural Resources.

Soliva, R., Hunziker, M., 2009. Beyond the visual dimension: using ideal type narratives to analyse people's assessments of landscape scenarios. Land Use Policy 26, 284-294.

Spooner, P., Lunt, I., Robinson, W., 2002. Is fencing enough? The short-term effects of stock exclusion in remnant grassy woodlands in southern NSW. Ecological Management and Restoration 3, 117-126.

Spooner, P.G., Briggs, S.V., 2008. Woodlands on farms in southern New South Wales: a longer-term assessment of vegetation changes after fencing. Ecological Management \& Restoration 9, 33-41.

Stedman, R.C., Beckley, T.M., Wallace, S.M., Ambard, M., 2004. A picture and 1000 words: using resident-employed photography to understand attachment to high amenity places. Journal of Leisure Research 36, 580-606.

Stern, P.C., 2000. Toward a coherent theory of environmentally significan behaviour. Journal of Social Issues 56, 407-424.

Stinner, D.H., Stinner, B.R., Martsolf, E., 1997. Biodiversity as an organizing principle in agroecosystem management: case studies of holistic resource management practitioners in the USA. Agriculture, Ecosystems \& Environment 62, 199213.

Ticehurst, J.L., Curtis, A., Merritt, W.S., 2009. Analysing social data on adoption of conservation practices: exploring Bayesian networks. In: Anderssen R.S., Braddock, R.D., Newham, L.T.H. (Eds.), 18th World IMACS Congress and MODSIM09 Congress on Modelling and Simulation. Modelling and Simulation Society of Australia and New Zealand and International Association for Mathematics and Computers in Simulation, Cairns, Australia pp. 2450-2456. 
Tonts, M. Halpin, D., Collins, J., Black, A., 2003. Rural Communities and Changing Farm Business Structures: An Assessment of the Socio-Economic Impacts. Rural Industries Research and Development Corporation, Canberra, ACT.

Tscharntke, T., Klein, A.M., Kruess, A., Steffan-Dewenter, I., Thies, C., 2005. Landscape perspectives on agricultural intensification and biodiversity-ecosystem service management. Ecology Letters 8, 857-874.

Vanclay, F., 2004. Social principles for agricultural extension to assist in the promotion of natural resource management. Australian Journal of Experimental Agriculture 44, 213-222.

Vesk, P.A., MacNally, R., 2006. The clock is ticking-revegetation and habitat for birds and arboreal mammals in rural landscapes of southern Australia. Agriculture, Ecosystems and Environment 112, 356-366.

Vouligny, É., Domon, G., Ruiz, J., 2009. An assessment of ordinary landscapes by an expert and by its residents: landscape values in areas of intensive agricultural use. Land Use Policy 26, 890-900.
Walpole, S.C., 1999. Assessment of the economic and ecological impacts of remnant vegetation on pasture productivity. Pacific Conservation Biology 5, 28-35.

Wang, C., Burris, M.A., Ping, X.Y., 1996. Chinese village women as visual anthropologists: a participatory approach to reaching policymakers. Social Science \& Medicine 42, 1391-1400.

Williams, D.R., Patterson, M.E., 2007. Snapshots of what, exactly? A comment on methodological experimentation and conceptual foundations in place research. Society and Natural Resources 20, 931-937.

Williams, K.J.H., Cary, J., 2002. Landscape preferences, ecological quality, and biodiversity protection. Environment and Behaviour 34, 257-274.

Wu, Y., Bishop, I., Hossain, H., Sposito, V., 2006. Using GIS in landscape visual quality assessment. Applied GIS 2, 18.1-18.20.

Wyborn, C., Cleland, D., in press. Fences and windows: using visual methods to explore conflicts in land and seascape management. In: Brown, V., Russell, J. Harris, J. (Eds.), Tackling Wicked Problems: Through the Transdiciplinary Imagination. Earthscan. http://www.earthscan.co.uk/?TabId=102293\&v=512016 